\title{
A systematic review and meta-analysis of the nutrient content of preterm and term breast milk
}

\author{
Dominica A Gidrewicz $^{1 *}$ and Tanis R Fenton ${ }^{2}$
}

\begin{abstract}
Background: Breast milk nutrient content varies with prematurity and postnatal age. Our aims were to conduct a meta-analysis of preterm and term breast milk nutrient content (energy, protein, lactose, oligosaccharides, fat, calcium, and phosphorus); and to assess the influence of gestational and postnatal age. Additionally we assessed for differences by laboratory methods for: energy (measured vs. calculated estimates) and protein (true protein measurement vs. the total nitrogen estimates).
\end{abstract}

Methods: Systematic review results were summarized graphically to illustrate the changes in composition over time for term and preterm milk. Since breast milk fat content varies within feeds and diurnally, to obtain accurate estimates we limited the meta-analyses for fat and energy to 24-hour breast milk collections.

Results: Forty-one studies met the inclusion criteria: 26 (843 mothers) preterm studies and 30 (2299 mothers) term studies of breast milk composition. Preterm milk was higher in true protein than term milk, with differences up to $35 \%(0.7 \mathrm{~g} / \mathrm{dL})$ in colostrum, however, after postnatal day 3, most of the differences in true protein between preterm and term milk were within $0.2 \mathrm{~g} / \mathrm{dL}$, and the week 10-12 estimates suggested that term milk may be the same as preterm milk by that age. Colostrum was higher than mature milk for protein, and lower than mature milk for energy, fat and lactose for both preterm and term milk. Breast milk composition was relatively stable between 2 and 12 weeks. With milk maturation, there was a narrowing of the protein variance. Energy estimates differed whether measured or calculated, from -9 to $13 \%$; true protein measurement vs. the total nitrogen estimates differed by 1 to $37 \%$.

Conclusions: Although breast milk is highly variable between individuals, postnatal age and gestational stage (preterm versus term) were found to be important predictors of breast milk content. Energy content of breast milk calculated from the macronutrients provides poor estimates of measured energy, and protein estimated from the nitrogen over-estimates the protein milk content. When breast milk energy, macronutrient and mineral content cannot be directly measured the average values from these meta-analyses may provide useful estimates of mother's milk energy and nutrient content.

Keywords: Human milk, Lactation, Breast milk, Infant, Premature

\section{Background}

Breast milk composition is variable. While breast milk is the recommended feeding for all infants [1-3], including preterm infants $[2,4,5]$, its variable composition makes estimating nutrient intakes difficult. Milk produced by mothers who deliver prematurely is well known to be higher in protein $[4,5]$. Milk composition changes with postnatal age; protein content decreases over weeks after

\footnotetext{
* Correspondence: dominica.gidrewicz@albertahealthservices.ca

${ }^{1}$ Department of Pediatrics, University of Calgary, 2888 Shaganappi Trail NW, Calgary, AB T3B 6A8, Canada

Full list of author information is available at the end of the article
}

birth [6]. Breast milk fat and energy content varies from the start to the end of a feeding, and follows a diurnal pattern in both term $[7,8]$ and preterm milk $[8,9]$.

In addition, there are several reasons for the variability in the values of breast milk composition due to laboratory methods used for the analysis. Two approaches have been used to quantify energy in breast milk: a) direct energy quantification by combusting in a bomb calorimetry and b) calculated energy estimates using Atwater energy multiplication factors for the macronutrients: protein, fat, and carbohydrate [10]. Two methods used to estimate protein 
content include a) direct quantification of the true protein content and b) quantification of the nitrogen (assuming that all nitrogen is protein, rather than recognition that some is in non-protein nitrogen compounds [11-13].

Thus we conducted a systematic review and metaanalysis of observational studies on the composition of breast milk nutrient content (energy, macronutrient (protein, lactose, fat)) and mineral content (calcium, phosphorus). We hypothesized that the composition of breast milk depends on four variables, which include: gestational stage (premature birth), postnatal age, calculated versus measured energy estimates, and protein method (true protein versus total nitrogen). We conducted the meta-analyses of breast milk composition stratified by these 4 factors (gestational stage; postnatal age; energy estimation method [measurement vs. calculation]; and protein estimation method [true protein versus total nitrogen]), to determine whether any or all of these factors should be considered when estimating breast milk nutrient content.

\section{Methods}

\section{Literature search}

In an attempt to find all published literature on the topic, studies relating to breast milk content in premature and mature milk were identified through computerized searches. First searches were conducted in MedLine and Embase for studies published in any language using the following Medical Subject Headings and text words: human, milk, lactation, breast milk, breast milk, protein, energy calories, lactose, oligosaccharide(s), fat, calcium, phosphorus, and infant, premature, preterm, neonate, or newborn, independently by the two investigators (DG and TRF) in March 2014. In an effort to include all available studies, a Web of Science search was conducted for all papers that cited the references Schanler et al. 1980 [14] and Atkinson SA et al. 1980 [15] (by DG). A grey literature search was also conducted to avoid reporting bias and look for unpublished literature (by DG) in March 2014. We reviewed the reference lists of included papers.

The inclusion criteria were: studies that reported on analysis of energy, macronutrient (protein, fat, lactose) and/or mineral (calcium, phosphorus) content in the breast milk of healthy, term (37-42 wk of gestation) and preterm (<37 wk of gestation) infants, if the data were reported categorized by postnatal age and term versus preterm status. Review articles and commentaries were excluded. Studies conducted in developing countries (i.e. outside North America, Europe, Australia, Israel and Japan [16]) were excluded in an attempt to exclude mothers with suboptimal nutritional status. The Metaanalysis Of Observational Studies in Epidemiology (MOOSE) Proposal for Reporting [17] was used to guide this study.

\section{Data extraction}

All article titles were examined for potential fit to the inclusion criteria by the two reviewers (DG and TRF). When the title was not clear regarding the potential fit, then the abstract was reviewed; when the abstract was not clear whether the study fit the inclusion criteria, the paper was reviewed. In studies where the data was presented in a non-numerical format, and thus not possible to include in a meta-analysis, efforts were made (by DG) to contact the author to obtain these data. If no response was received to the request or the author was unable to provide additional data, the study was not included in the meta-analysis. Data were extracted by DG and checked for accuracy by TRF.

Since breast milk fat content varies between fore and hind milk [6,7] and diurnally between early and later in the day [7-9], to obtain accurate estimates we limited the meta-analyses for energy and fat to 24-hour breast milk collections. This requirement was not placed on the other analyses since the differences between fore and hind milk and diurnally in protein are not of an important magnitude [6,7].

\section{Analysis}

Meta-analyses were carried out on studies that reported the following outcomes in either healthy, term or preterm delivering mothers: total energy $(\mathrm{kcal} / \mathrm{dL})$, protein $(\mathrm{g} / \mathrm{dL})$, fat $(\mathrm{g} / \mathrm{dL})$, lactose content $(\mathrm{kcal} / \mathrm{dL})$, calcium $(\mathrm{mg} / \mathrm{dL})$, and phosphate $(\mathrm{mg} / \mathrm{dL})$. Data was grouped into the following time points: 1-3 days (representing colostrum), 4 to 7 days, week 2 (day 8-14), week 3-4 (days 15-28), week 5-6 (days 29-42), week 7-9 (days 43 - 63), week 10-12 (days 64-84). We continued the meta-analyses to 12 weeks since age-specific data was sparse for the analyses after this age.

To examine whether the two energy measures, bomb calorimetry and calculation methods, estimated different energy contents, separate meta-analyses were prepared for each energy estimation method and compared. Energy reported as kilojoules was converted to kilocalories by dividing by 4.184 .

Historically, protein in breast milk has been estimated in two different ways: including or excluding the nonprotein nitrogen. Thus, we conducted two meta-analyses of protein for the available data: an estimate of protein based on the assumption that all of the nitrogen is protein and a true protein estimate which excludes the nonprotein nitrogen. When only total protein was only reported in terms of total nitrogen, total protein was calculated by multiplying the nitrogen by 6.25 [12-14,18-23].

Mineral data reported as millimoles was converted to milligrams by multiplying by the molecular weight. Breast milk data reported per kilogram was converted to per liter by dividing by 1.032 [24]. 
Table 1 Studies included in the meta-analysis

\begin{tabular}{|c|c|c|c|c|c|c|}
\hline \multirow[t]{2}{*}{ Reference } & \multirow[t]{2}{*}{ Site } & \multicolumn{4}{|c|}{ Subjects } & \multirow[t]{2}{*}{ Reported outcomes } \\
\hline & & Preterm & $\mathrm{n}$ & Term & $\mathrm{n}$ & \\
\hline Anderson et al., 1983 [18] & US & 28-36 weeks & 14 & 37-42 weeks & 9 & E, Pro, fat \\
\hline Arnold et al., 1987 [130] & Australia & 26-33 weeks & 6 & 38-40 weeks & 7 & Pro, lactose \\
\hline Atkinson et al., 1980 [15] & Canada & 26-33 weeks & 13 & 38-40 weeks & 10 & $\mathrm{Ca}, \mathrm{P}$ \\
\hline Atkinson et al., 1981 [19] & Canada & $B W<1300 \mathrm{~g}$ & 7 & - & & E, Pro, lactose, fat \\
\hline Bejiers et al., 1992 [128] & Netherlands & 25.7-30.9 weeks & 30 & - & & Pro \\
\hline Britton et al., 1986 [137] & US & 25-35 weeks & 70 & 38-42 weeks & 38 & Pro \\
\hline Butte et al., 1984 [13] & US & $<37$ weeks & 8 & $\geq 37$ weeks & 13 & Pro, Ca, P \\
\hline Butte et al., 1984 [122] & US & - & & Term & 40 & E, Pro, fat \\
\hline Butte NF et al., 1990 [123] & US & - & & $39.9 \pm 0.9$ weeks & 40 & E, Pro, lactose, fat \\
\hline Coppa et al., 1993 [140] & Italy & - & & Term & 46 & Lactose, oligo \\
\hline Coppa et al., 1997 [141] & Italy & 27-35 weeks & 26 & - & & Oligo \\
\hline Corvaglia et al., 2008 [20] & Italy & 26-32 weeks & 55 & 37-41 weeks & 69 & Pro \\
\hline Cregan MD, 2002 [135] & Australia & 31-35 weeks & 22 & $>38$ weeks & 16 & Pro, lactose \\
\hline Ehrenkranz et al., 1984 [142] & US & 26-33 weeks & 21 & - & & fat \\
\hline Faerk et al., 2001 [133] & Denmark & $<32$ weeks & 101 & - & & Pro \\
\hline Ferris et al., 1988 [21] & US & - & & $>37$ weeks & 12 & Pro, lactose \\
\hline Garza et al., [124] & US & - & & Term & 10 & E \\
\hline Gabrielli et al., 2011 [143] & Italy & 25-30 weeks & 63 & - & & Lactose, oligo \\
\hline Gross et al., 1980 [131] & US & 28-36 weeks & 33 & 38-42 weeks & 18 & Pro, lactose, Ca \\
\hline Guerrini et al., 1981 [144] & Italy & 29-37 weeks & 25 & 38-42 weeks & 47 & fat \\
\hline Hibberd et al., 1982 [11] & UK, Germany & - & & > 37 weeks & 10 & E, Pro, lactose, fat, Ca \\
\hline Hosoi et al., 2005 [134] & Japan & - & & Term & 114 & Pro \\
\hline Hurgoiu et al., 1986 [145] & Romania & 27-34 weeks & 28 & - & & $\mathrm{Ca}$ \\
\hline Itabashi et al., 1999 [129] & Japan & 26-33 weeks & 15 & - & & Pro, lactose, $\mathrm{Ca}, \mathrm{P}$ \\
\hline Lepage et al., 1984 [120] & Canada, US & 26-36 weeks & 32 & $>37$ weeks & 19 & E, Pro \\
\hline Lemons et al., 1982 [12] & US & 27-37 weeks & 20 & 39-41 weeks & 7 & E, Pro, lactose, fat, Ca, P \\
\hline Maas et al., 1998 [22] & Netherlands & 25-29 weeks & 79 & - & & E, Pro, lactose, fat \\
\hline Michaelsen et al., 1994 [139] & Denmark & - & & 37-41weeks & 91 & Pro, fat, lactose \\
\hline Montagne et al., 1999 [136] & France & $<37$ weeks & 46 & $>37$ weeks & 28 & Pro \\
\hline Motil et al., 1997 [125] & US & - & & 38-42 weeks & 10 & E, Pro \\
\hline Nommsen et al., 1991 [127] & US & - & & Term & 58 & E, Pro, fat \\
\hline Reinken et al., 1985 [132] & Germany & 28-33 weeks & 16 & 38-40 weeks & 24 & Pro \\
\hline Saarela et al., 2005 [6] & Finland & $31.4 \pm 3$ weeks & 36 & $40.2 \pm 1.4$ weeks & 53 & E, Pro, lactose, fat \\
\hline Sadurskis et al., 1998 [119] & Sweden & & & Term & 23 & E \\
\hline Sanchez-Pozo et al., 1986 [138] & Spain & & & Term & 209 & Protein \\
\hline Sann et al., 1981 [146] & France & 26-35 weeks & 41 & 38-41 weeks & 61 & Pro, lactose, fat, Ca, P, \\
\hline Schanler et al., 1980 [14] & US & $29.7 \pm 0.5$ weeks & 16 & - & & Pro, Ca \\
\hline Thomas et al., 1986 [121] & US & 30-34 weeks & 20 & - & & E, Pro, lactose, fat \\
\hline Yamawaki et al., 2005 [23] & Japan & - & & $\mathrm{BW}>2500 \mathrm{~g}$ & 1180 & Pro, lactose, Ca, P \\
\hline Viverge et al., 1990 [147] & France & - & & Term & 15 & Lactose, oligo \\
\hline Wood et al., 1988 [126] & US & - & & 37-42 weeks & 22 & E \\
\hline Total & & & 843 & & 2299 & \\
\hline
\end{tabular}

$\mathrm{E}=$ energy, Pro $=$ protein, oligo $=$ oligosaccharides, $\mathrm{Ca}=$ calcium, $\mathrm{P}=$ phosphate, $\mathrm{BW}=$ birth weight, $\mathrm{g}=$ gram, $\mathrm{UK}=$ United Kingdom, US $=$ United States. 


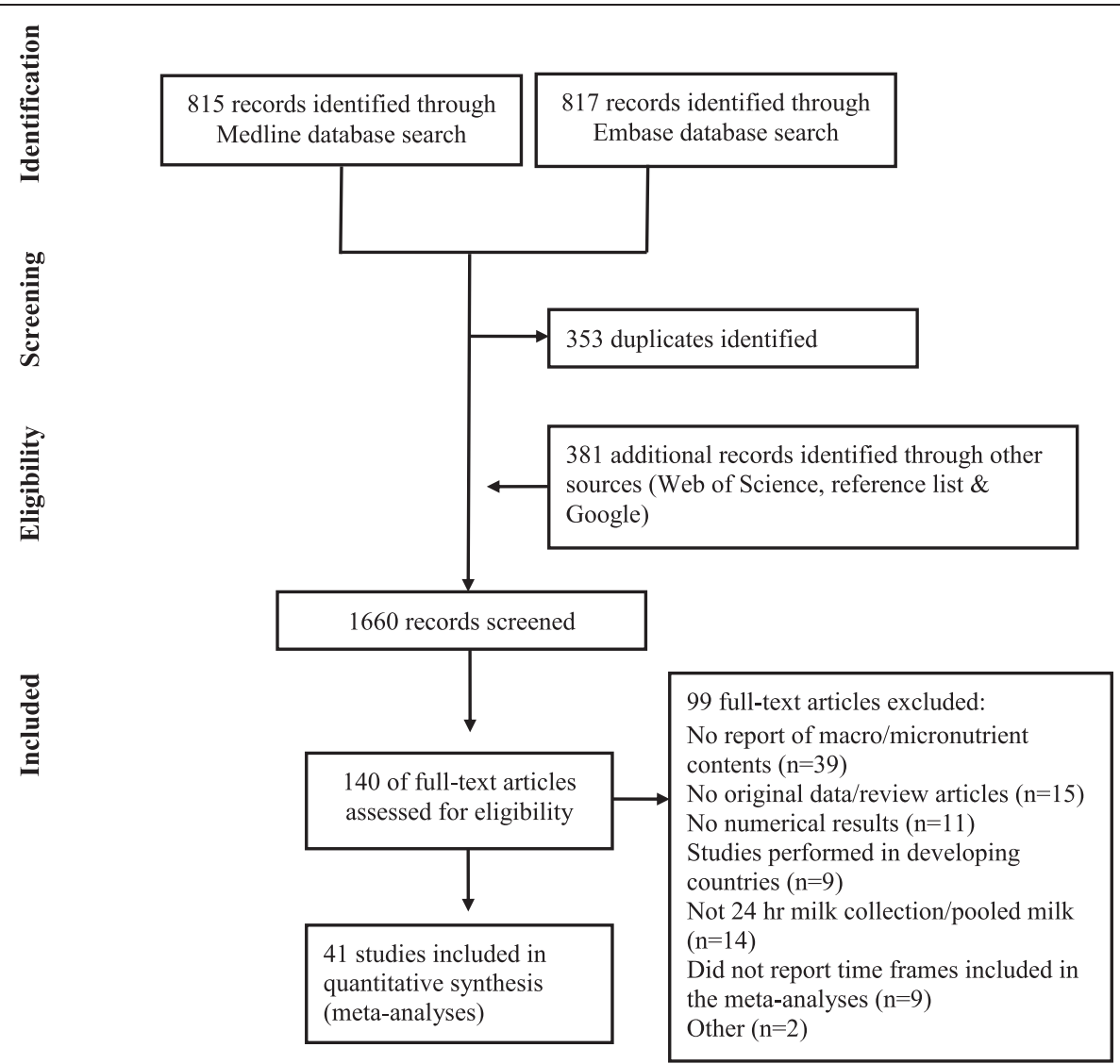

Figure 1 Flow diagram of the literature search process.

The nutrient content meta-analyses were calculated as weighted averages and pooled standard deviation for each time period, for preterm and term breast milk. For statistical comparisons, t-tests were used to compare preterm and term milk composition. Given the multiple comparisons made in this study, an approximate Bonferroni adjustment was made, and the p-value for statistical significance used was 0.001 .

\section{Results}

A total of 41 studies were included in the analysis: 26 (843 mothers) and 30 (2299 mothers) studies reporting on preterm and term breast milk composition, respectively (Table 1). Attempts were made to contact authors of nine studies, we received replies from four, but no additional information was received for the meta-analyses. Ninety-nine studies were excluded for reasons provided in Figure 1: no

Table 2 Meta-analysis summary estimates of breast milk composition per 100 milliliters at various postnatal ages (mean (+/-2 standard deviations))

\begin{tabular}{llllll}
\hline Preterm & Energy (kcal) & Protein $\mathbf{( g )}$ & Fat $\mathbf{( g )}$ & Calcium (mg) & Phosphorus (mg) \\
\hline $1^{\text {st }}$ week & $60(45-75)$ & $2.2(0.3-4.1)$ & $2.6(0.5-4.7)$ & $26(9-43)$ & $11(1-22)$ \\
$2^{\text {nd }}$ week & $71(49-94)$ & $1.5(0.8-2.3)$ & $3.5(1.2-5.7)$ & $25(11-39)$ & $15(8-21)$ \\
Week 3/4 & $77(61-92)$ & $1.4(0.6-2.2)$ & $3.5(1.6-5.5)$ & $25(13-36)$ & $14(8-20)$ \\
Week 10/12 & $66(39-94)$ & $1.0(0.6-1.4)$ & $3.7(0.8-6.5)$ & $29(19-38)$ & $12(8-15)$ \\
\hline Term & Energy (kcal) & Protein (g) & Fat (g) & Calcium (mg) & Phosphorus (mg) \\
\hline $1^{\text {st }}$ week & $60(44-77)$ & $1.8(0.4-3.2)$ & $2.2(0.7-3.7)$ & $26(16-36)$ & $12(6-18)$ \\
$2^{\text {nd }}$ week & $67(47-86)$ & $1.3(0.8-1.8)$ & $3.0(1.2-4.8)$ & $28(14-42)$ & $17(8-27)$ \\
Week 3/4 & $66(48-85)$ & $1.2(0.8-1.6)$ & $3.3(1.6-5.1)$ & $27(18-36)$ & $16(10-22)$ \\
Week 10/12 & $68(50-86)$ & $0.9(0.6-1.2)$ & $3.4(1.6-5.2)$ & $26(14-38)$ & $16(9-22)$ \\
\hline
\end{tabular}

Estimates as $+/-2$ standard deviations assumed no skew. Energy values were bomb calorimeter measured values except for 10-12 weeks, which were calculated values. Protein values are true measured protein, not based on total nitrogen content. 
Table 3 Meta-analysis results of preterm and term breast milk energy content over time from measured and calculated estimates

\begin{tabular}{|c|c|c|c|c|c|c|c|c|}
\hline \multicolumn{9}{|c|}{ Comparison: Bomb calorimetry energy measurement (kcal/dL) } \\
\hline \multirow[b]{2}{*}{ Time frame: } & \multirow{2}{*}{$\begin{array}{c}\text { Preterm } \\
\text { mean }\end{array}$} & \multirow[b]{2}{*}{ SD } & \multirow[b]{2}{*}{$\mathbf{n}$} & \multirow{2}{*}{$\begin{array}{l}\text { Term } \\
\text { Mean }\end{array}$} & \multirow[b]{2}{*}{ SD } & \multirow[b]{2}{*}{$\mathbf{n}$} & \multicolumn{2}{|c|}{ Preterm \& term compared } \\
\hline & & & & & & & $\%$ difference & p-value \\
\hline d $1-3$ & 49 & 7 & 12 & 54 & 8 & 19 & -10 & 0.34 \\
\hline d $4-7$ & 71 & 9 & 52 & 66 & 9 & 37 & 7 & 0.02 \\
\hline week 2 & 71 & 12 & 53 & 66 & 9 & 34 & 7 & 0.04 \\
\hline week 3-4 & 77 & 8 & 27 & 66 & 8 & 97 & 16 & $<0.00001^{*}$ \\
\hline week 5-6 & 70 & 5 & 14 & 63 & 7 & 40 & 11 & $<0.00001^{*}$ \\
\hline week 7-9 & 76 & 8 & 11 & 63 & 7 & 77 & 21 & $<0.00001^{*}$ \\
\hline week 10-12 & - & - & - & 63 & 8 & 83 & - & - \\
\hline
\end{tabular}

Energy meta-analysis was limited to 24 hour collections

- References: [11,12,18,119-126]

\begin{tabular}{|c|c|c|c|c|c|c|c|c|}
\hline \multicolumn{9}{|c|}{ Comparison: Calculated energy content (kcal/dL) } \\
\hline \multirow[b]{2}{*}{ Time frame: } & \multirow{2}{*}{$\begin{array}{c}\text { Preterm } \\
\text { mean }\end{array}$} & \multirow[b]{2}{*}{ SD } & \multirow[b]{2}{*}{$\mathbf{n}$} & \multirow{2}{*}{$\begin{array}{l}\text { Term } \\
\text { Mean }\end{array}$} & \multirow[b]{2}{*}{ SD } & \multirow[b]{2}{*}{$\mathbf{n}$} & \multicolumn{2}{|c|}{ Preterm \& term compared } \\
\hline & & & & & & & $\%$ difference & $\mathrm{p}$-value \\
\hline d $1-3$ & - & - & - & - & - & - & & \\
\hline d $4-7$ & 65 & 13 & 41 & 68 & 9.6 & 48 & -5 & 0.21 \\
\hline week 2 & 70 & 14 & 95 & - & - & - & & \\
\hline week 3-4 & 68 & 8.0 & 135 & 70 & 9.3 & 46 & -2 & 0.26 \\
\hline week 5-6 & 67 & 6.9 & 79 & - & - & - & & \\
\hline week 7-9 & 66 & 8.9 & 63 & 69 & 9.9 & 43 & -4 & 0.16 \\
\hline week 10-12 & 66 & 14 & 14 & 68 & 9.0 & 95 & -3 & 0.50 \\
\hline \multicolumn{9}{|c|}{ References: $[6,19,22,121,127]$} \\
\hline \multicolumn{9}{|c|}{ Comparison: Measured vs. calculated energy } \\
\hline & Preterm & & Term & & & & & \\
\hline & Difference & $\%$ difference & p-value & Difference & $\%$ difference & p-value & & \\
\hline d $1-3$ & & - & - & & - & - & & \\
\hline d 4-7 & 6 & $-9 \%$ & 0.009 & -2 & $2 \%$ & 0.350 & & \\
\hline week 2 & 1 & $-2 \%$ & 0.66 & & & & & \\
\hline week 3-4 & 9 & $-11 \%$ & $<0.00001^{*}$ & -3 & $5 \%$ & 0.007 & & \\
\hline week 5-6 & 3 & $-5 \%$ & 0.11 & & & & & \\
\hline week 7-9 & 10 & $-13 \%$ & $0.0009^{*}$ & -6 & $9 \%$ & $0.0003^{*}$ & & \\
\hline week 10-12 & & & & -5 & $9 \%$ & $0.0002^{*}$ & & \\
\hline
\end{tabular}

*Statistically significant difference. In compensation for multiple comparisons, an approximate Bonferroni adjustment was made and the p-value for statistical significance was $<0.001$.

original data/review articles [25-39], studies performed in developing countries [40-48], no numerical results [49-59], not 24-hour milk collection/pooled milk (required only for energy and fat contents) [7-9,60-70], no report of macro/micronutrient contents [36,71-107], did not report time frames used in the meta-analyses [108-116], other $[117,118]$. Energy was estimated in 11 studies using bomb calorimetry [11,12,18,119-126] and in five studies by calculation using values for the energy contributions from fat, protein, and carbohydrate $[6,19,22,121,127]$. Protein was estimated based on total nitrogen in 23 studies
[6,11-14,18-23,120,122,123,125,128-135] and as a true protein estimate in 15 studies [11-14,18,19,121-123,127-129, 136-139]. A summary of the meta-analyses breast milk composition at various postnatal ages for energy, protein, fat, calcium and phosphorus is outlined in Table 2.

\section{Energy measurement vs. calculation from the} macronutrients

In the comparison between measured and calculated energy contents of milk, measured estimates were -6 to $10 \mathrm{kcal} / \mathrm{dL}(-9$ to $13 \%)$ greater than the calculated 


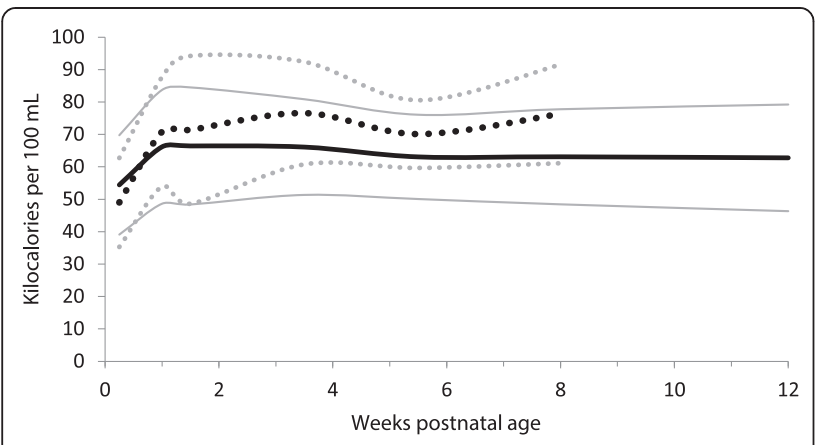

Figure 2 Measured Energy distribution of preterm and term breast milk by postnatal age over the first 12 weeks of lactation, weighted mean and $\mathbf{9 5 \%}$ reference interval. Preterm milk $\cdots$.. Term milk - - : mean $+/-2$ standard deviations.

analyses (Table 3, Figures 2 and 3), but only four differences (preterm milk at weeks 3-4 and 7-9, term milk at weeks 7-9 and 10-12 weeks) met the adjusted statistical significance criteria (i.e. $\mathrm{p}<0.001$ ). Most of the preterm measured energy estimates had less than 30 subjects (Table 3), and while the calculated energy estimates generally had higher numbers; none of the studies that reported calculated energy estimates had any data for the first few postnatal days (Figure 2 and 3, Table 3).

\section{Protein estimation method [true protein versus total nitrogen estimate]}

Almost all of the differences in protein content, between the estimates of protein based on total nitrogen content and the measured true protein estimates were statistically significantly lower for the true protein measures for most time periods, for both term and preterm milk, (Table 4, Figures 4 and 5). The most common differences in quantity between the total nitrogen and true protein estimates was $0.3 \mathrm{~g} / \mathrm{dL}$ (Table 4).

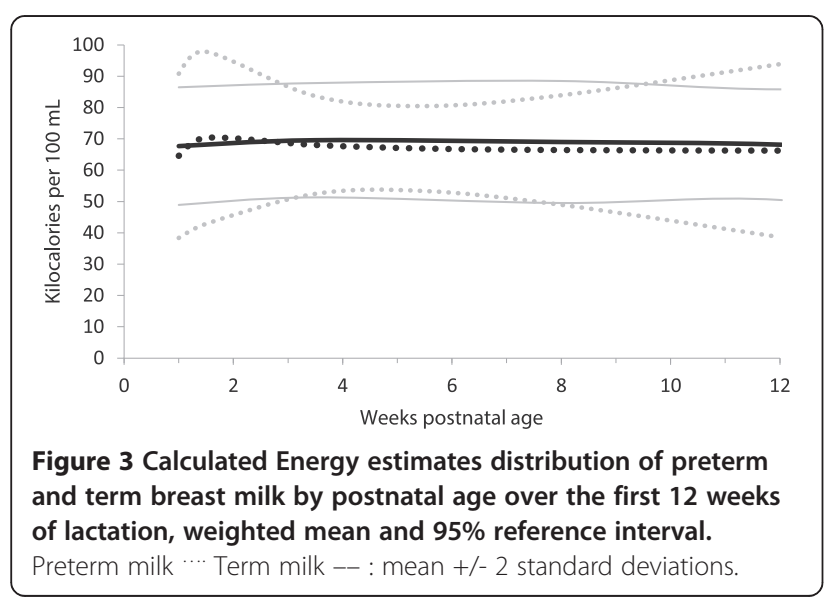

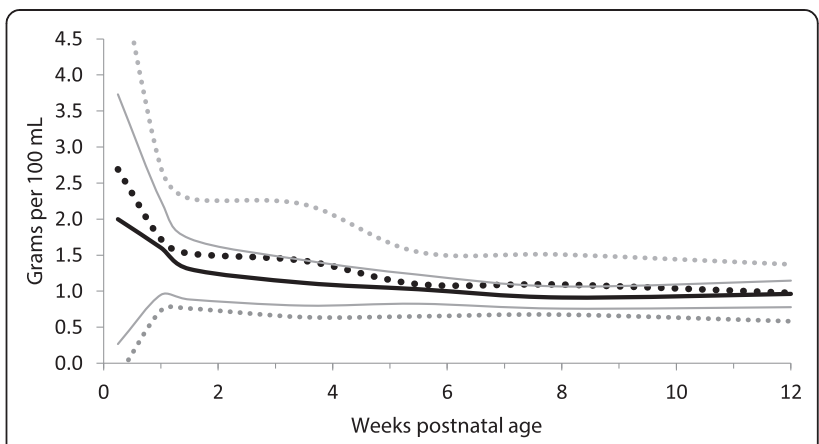

Figure 4 True Protein content distribution of preterm and term breast milk in by postnatal age over the first 12 weeks of lactation, weighted mean and $95 \%$ reference interval. Preterm milk $\cdots$ Term milk - - : mean $+/-2$ standard deviations.

\section{Gestational stage effect: preterm milk compared to term milk}

In a comparison of the term versus preterm milk, most of the analytes (with the exception of fat and calculated energy) had some differences between the preterm and term milk composition that were statistically significant (Tables 3, 4, 5, 6, 7).

The energy content of preterm milk was similar to term milk at all postnatal ages, with three significant differences for the bomb calorimetric methods between 3 to 9 weeks; with differences of $-10-21 \%$ (Table 3, Figures 2 and 3). We found no measured energy content data on preterm milk after 9 weeks.

Preterm milk was higher in true protein than term milk, with maximum mean differences up to $35 \%(0.7 \mathrm{~g} / \mathrm{dl})$ in the first few days after birth (Table 4, Figure 4). However, after postnatal day 3 , most of the differences in true protein between preterm and term milk were within $0.2 \mathrm{~g} / \mathrm{dL}$ or less, and the week $10-12$ estimates suggested that term milk may be the same as preterm milk by that age. The estimates of protein based on total

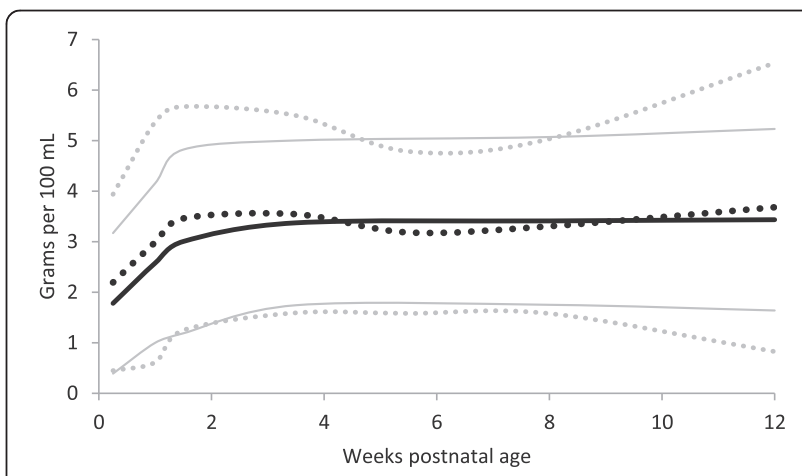

Figure 5 Fat content distribution of preterm and term breast milk by postnatal age over the first 12 weeks of lactation, weighted mean and $95 \%$ reference interval. Preterm milk $\cdots$. Term milk - - : mean +/- 2 standard deviations. 
Table 4 Meta-analysis results of preterm and term breast milk protein content over time

\begin{tabular}{|c|c|c|c|c|c|c|c|c|}
\hline \multicolumn{9}{|c|}{ Comparison: True protein comparisons: Preterm vs. term (g/dL) } \\
\hline \multirow[b]{2}{*}{ Time frame: } & \multicolumn{3}{|c|}{ Preterm } & \multicolumn{2}{|c|}{ Term } & \multicolumn{3}{|c|}{ Preterm \& term compared } \\
\hline & mean & SD & $\mathbf{n}$ & mean & SD & $\mathbf{n}$ & $\%$ difference & p-values \\
\hline d $1-3$ & 2.7 & 1.5 & 141 & 2.0 & 0.9 & 108 & 35 & $<0.00001^{*}$ \\
\hline d 4-7 & 1.7 & 0.5 & 165 & 1.6 & 0.3 & 185 & 7 & 0.005 \\
\hline week 2 & 1.5 & 0.4 & 191 & 1.3 & 0.2 & 256 & 16 & $<0.00001^{*}$ \\
\hline week 3-4 & 1.4 & 0.4 & 92 & 1.1 & 0.2 & 194 & 27 & $<0.00001^{*}$ \\
\hline week 5-6 & 1.1 & 0.2 & 38 & 1.0 & 0.1 & 85 & 7 & 0.0003 \\
\hline week 7-9 & 1.1 & 0.2 & 30 & 0.9 & 0.1 & 113 & 20 & $<0.00001^{*}$ \\
\hline week 10-12 & 1.0 & 0.2 & 25 & 1.0 & 0.1 & 221 & 2 & 0.37 \\
\hline
\end{tabular}

- References: [11-14,18,19,121-123,127-129,136-139]

Comparison: Total protein comparisons: Preterm vs. term (g/dL)

\begin{tabular}{|c|c|c|c|c|c|c|c|c|}
\hline \multirow[b]{2}{*}{ Time frame: } & \multicolumn{3}{|c|}{ Preterm } & \multicolumn{2}{|c|}{ Term } & \multicolumn{3}{|c|}{ Preterm \& term compared } \\
\hline & mean & SD & $\mathbf{n}$ & mean & SD & $\mathbf{n}$ & $\%$ difference & p-values \\
\hline d $1-3$ & 2.8 & 1.1 & 94 & 2.0 & 0.6 & 168 & 37 & $<0.00001^{*}$ \\
\hline d 4-7 & 2.1 & 0.5 & 244 & 2.0 & 0.5 & 229 & 4 & 0.04 \\
\hline week 2 & 1.9 & 0.4 & 253 & 1.8 & 0.4 & 192 & 8 & $<0.00001^{*}$ \\
\hline week 3-4 & 1.6 & 0.4 & 439 & 1.5 & 0.3 & 210 & 9 & 0.01 \\
\hline week 5-6 & 1.4 & 0.3 & 268 & 1.1 & 0.2 & 357 & 18 & $<0.00001^{*}$ \\
\hline week 7-9 & 1.1 & 0.2 & 183 & 1.3 & 0.2 & 453 & -10 & $<0.00001^{*}$ \\
\hline week 10-12 & 1.3 & 0.3 & 18 & 1.2 & 0.2 & 109 & 12 & 0.07 \\
\hline
\end{tabular}

Comparisons: True vs. Total protein «»

\begin{tabular}{|c|c|c|c|c|c|c|}
\hline & Difference & $\%$ difference & p-value & Difference & $\%$ difference & p-value \\
\hline d $1-3$ & 0.1 & $4 \%$ & 0.60 & 0 & $1 \%$ & 0.91 \\
\hline d 4-7 & 0.3 & $20 \%$ & $<0.00001^{*}$ & 0.4 & $24 \%$ & $<0.00001^{*}$ \\
\hline week 2 & 0.4 & $26 \%$ & $<0.00001^{*}$ & 0.5 & $36 \%$ & $<0.00001^{*}$ \\
\hline week 3-4 & 0.2 & $12 \%$ & $<0.00001^{*}$ & 0.4 & $31 \%$ & $<0.00001^{*}$ \\
\hline week 5-6 & 0.3 & $27 \%$ & $<0.00001^{*}$ & 0.1 & $11 \%$ & $<0.00001^{*}$ \\
\hline week 7-9 & 0 & $3 \%$ & 0.35 & 0.3 & $37 \%$ & $<0.00001^{*}$ \\
\hline week 10-12 & 0.3 & $32 \%$ & 0.0002 & 0.2 & $20 \%$ & $<0.00001^{*}$ \\
\hline
\end{tabular}

Estimates based on true protein content versus the assumption that all nitrogen is protein.

*Statistically significant difference. In compensation for multiple comparisons, an approximate Bonferroni adjustment was made and the p-value for statistical significance was $<0.001$.

nitrogen suggested differences between preterm and term milk as high as $37 \%(0.8 \mathrm{~g} / \mathrm{dl})$ in the first few days, however after day 3 , the most common difference between preterm and term protein estimates based on total nitrogen was $0.1 \mathrm{~g} / \mathrm{dL}$ (Table 4 ).

The fat content of the preterm milk did not differ statistically (all p-values $>0.001$ ) between preterm and term milk at any point in time, even though preterm milk was $23 \%$ higher than term milk (non-significant) in the first few days of life (Table 5, Figure 5).

Lactose was significantly lower in preterm milk compared to term milk, in the first 3 days and at a few later time points (Table 5, Figure 6). The general pattern of oligosaccharides showed similarities between preterm and term milk, although there was limited data for preterm milk (data only on days 4 - week 4) (Table 5, Figure 7). One difference was statistically significant for days 4-7 when preterm milk was $12 \%$ higher than term milk.

The minerals, calcium and phosphate, were mostly similar between preterm and term milk. (Table 6, Figures 8 and 9).

\section{The milk maturity effect}

In general, the meta-analyses of breast milk composition revealed relatively stable milk content between 2 and 12 weeks, after the initial fluctuations as the milk changed from colostrum to more mature milk (Tables 3, 4, 5, 6 and 7, Figures 2, 3, 4, 5, 6, 7, 8 and 9). The 
Table 5 Meta-analysis results of preterm and term breast milk fat, lactose and oligosaccharide content over time

\begin{tabular}{|c|c|c|c|c|c|c|c|c|}
\hline Fat $(g / d L)$ & \multicolumn{3}{|c|}{ Preterm } & \multicolumn{3}{|c|}{ Term } & \multicolumn{2}{|c|}{ Preterm \& term compared } \\
\hline Time frame: & mean & SD & $\mathbf{n}$ & mean & SD & $\mathbf{n}$ & $\%$ difference & $\mathrm{p}$-value \\
\hline d $1-3$ & 2.2 & 0.9 & 76 & 1.8 & 0.7 & 74 & 23 & 0.002 \\
\hline d 4-7 & 3.0 & 1.2 & 111 & 2.6 & 0.8 & 136 & 16 & 0.002 \\
\hline week 2 & 3.5 & 1.1 & 158 & 3.0 & 0.9 & 48 & 15 & 0.01 \\
\hline week 3-4 & 3.5 & 1.0 & 180 & 3.4 & 0.8 & 127 & 5 & 0.12 \\
\hline week 5-6 & 3.2 & 0.8 & 95 & 3.6 & 1.1 & 20 & -11 & 0.07 \\
\hline week 7-9 & 3.3 & 0.9 & 120 & 3.4 & 0.8 & 83 & -3 & 0.38 \\
\hline week 10-12 & 3.7 & 1.5 & 22 & 3.4 & 0.9 & 95 & 7 & 0.31 \\
\hline
\end{tabular}

Fat meta-analysis was limited to 24 hour collections.

- References: $[6,11,12,18,19,22,121-123,125,127,142,144,146]$

\begin{tabular}{|c|c|c|c|c|c|c|c|c|}
\hline \multicolumn{9}{|l|}{ Lactose (kcal/dL) } \\
\hline Time frame: & mean & SD & $\mathbf{n}$ & mean & SD & $\mathrm{n}$ & $\%$ difference & p-value \\
\hline d $1-3$ & 5.1 & 0.7 & 95 & 5.6 & 0.6 & 59 & -9 & $<0.00001^{*}$ \\
\hline d 4-7 & 6.3 & 1.1 & 114 & 6.0 & 1.0 & 281 & 4 & 0.009 \\
\hline week 2 & 5.7 & 0.8 & 231 & 6.2 & 0.6 & 100 & -8 & $<0.00001^{*}$ \\
\hline week 3-4 & 6.0 & 0.5 & 225 & 6.7 & 0.7 & 193 & -10 & $<0.00001^{*}$ \\
\hline week 5-6 & 5.8 & 0.6 & 104 & 6.1 & 1.0 & 22 & -6 & 0.06 \\
\hline week 7-9 & 6.3 & 0.4 & 123 & 6.5 & 0.5 & 646 & -2 & $<0.00001^{*}$ \\
\hline week 10-12 & 6.8 & 0.3 & 28 & 6.7 & 0.7 & 58 & 2 & 0.47 \\
\hline \multicolumn{9}{|c|}{ References: $[6,11,12,19,21-23,121,123,129-131,135,140,143,146,147]$} \\
\hline \multicolumn{9}{|c|}{ Oligosaccharides (g/dL) } \\
\hline Time frame: & mean & SD & $\mathbf{n}$ & mean & SD & $\mathbf{n}$ & $\%$ difference & p-value \\
\hline d 1-3 & - & - & - & 1.6 & 0.2 & 9 & - & - \\
\hline days $4-7$ & 2.1 & 0.4 & 89 & 1.9 & 0.4 & 93 & 12 & 0.0009 \\
\hline week 2 (days 7-14) & 2.1 & 0.5 & 89 & 1.9 & 0.4 & 54 & 7 & 0.004 \\
\hline week 3-4 (days 15-30) & 1.7 & 0.3 & 152 & 1.6 & 0.3 & 46 & 12 & 0.27 \\
\hline week 5-6 & - & - & - & 1.4 & 0.3 & 46 & - & - \\
\hline week 7-9 & - & - & - & 1.3 & 0.3 & 46 & - & - \\
\hline week 10-12 & - & - & - & - & - & - & - & - \\
\hline
\end{tabular}

*Statistically significant difference. In compensation for multiple comparisons, an approximate Bonferroni adjustment was made and the p-value for statistical significance was $<0.001$.

composition of colostrum compared to more mature milk (5 to 12 weeks) differed for all of the macronutrients by $16 \%$ or more (Table 2, Figures 2, 3, 4, 5, 6 and 7). Compared to colostrum, mature milk protein content decreased dramatically while fat increased by approximately one half in preterm milk or doubled in term milk. Measured energy and lactose were higher in mature milk compared to colostrum (Tables 3 and 5 Figures 2 and 6).

With milk maturation, there was a notable narrowing of the true protein variance in preterm milk, from the wide estimated 0 to $5.7 \mathrm{~g} / \mathrm{dL}$ reference interval $(+/-2$ standard deviations) in colostrum to the narrower mature milk estimated 0.6 to $1.4 \mathrm{~g} / \mathrm{dL}$ at 12 weeks.

\section{Discussion}

Much has been written about the differences between preterm and term breast milk, particularly about the nutritional superiority of preterm milk. This meta-analysis revealed more similarities than differences between preterm and term milk for energy, fat, oligosaccharides, calcium, and phosphorus. Gestational age (preterm vs term milk); postnatal age; protein estimation method [true protein versus total nitrogen estimate] and energy 
Table 6 Meta-analysis results of preterm and term breast milk mineral content over time

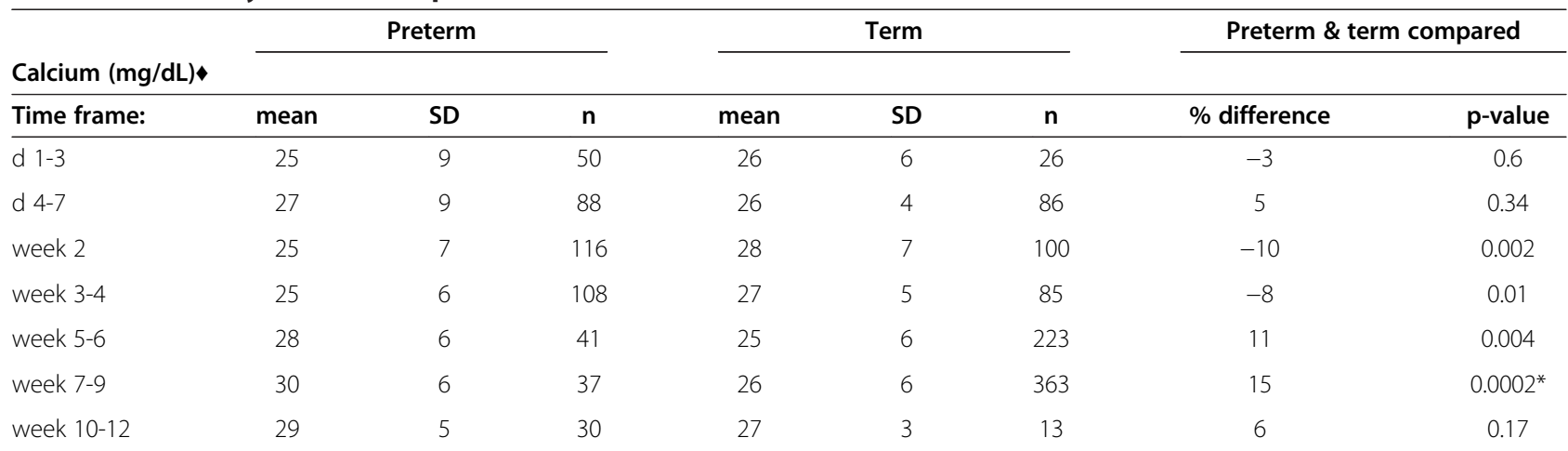

- References: [11-15,23,88,129,131,145,146]

\section{Phosphate $(\mathrm{mg} / \mathrm{dL}) \bullet$}

\begin{tabular}{|c|c|c|c|c|c|c|c|c|}
\hline Time frame: & mean & SD & $\mathbf{n}$ & mean & SD & $\mathrm{n}$ & $\%$ difference & $p$-value \\
\hline d $1-3$ & 10 & 7 & 7 & 11 & 3 & 6 & -14 & 0.62 \\
\hline d 4-7 & 13 & 4 & 79 & 13 & 4 & 86 & 3 & 0.50 \\
\hline week 2 & 15 & 3 & 67 & 15 & 4 & 90 & -4 & 0.44 \\
\hline week 3-4 & 14 & 3 & 56 & 16 & 3 & 75 & -14 & $0.0004^{*}$ \\
\hline week 5-6 & 13 & 2 & 33 & 16 & 3 & 213 & -16 & $<0.0001^{*}$ \\
\hline week 7-9 & 14 & 2 & 29 & 16 & 3 & 363 & -13 & 0.002 \\
\hline week 10-12 & 12 & 2 & 22 & 14 & 3 & 13 & -19 & 0.03 \\
\hline
\end{tabular}

$\leftrightarrow$ References: $[12,13,15,23,88,129,131,146]$

*Statistically significant difference. In compensation for multiple comparisons, an approximate Bonferroni adjustment was made and the p-value for statistical significance was $<0.001$.

estimation method [measured versus calculated] were each found to identify important differences in breast milk content. Thus these factors should be considered when estimating breast milk nutrient content and in designing future studies to analyze breast milk nutrient content.

For energy, the differences between measured and calculated estimates of breast milk composition were only significantly different at three time points for preterm milk, however, the differences were as high as $10 \mathrm{kcal} / \mathrm{dL}$ (13\%), which are likely clinically important differences. This data suggests that measured energy content of breast milk is superior to calculated methods.

It is possible that errors in the calculation of energy content of milk could be due to the various conversion

Table 7 The milk maturity effect: Comparison of colostrum versus mature milk

\begin{tabular}{|c|c|c|c|c|c|c|c|c|}
\hline & \multicolumn{2}{|c|}{ Energy (measured) } & \multicolumn{2}{|c|}{ Protein (true protein) } & \multicolumn{2}{|c|}{ Fat } & \multicolumn{2}{|c|}{ Lactose } \\
\hline & Preterm & Term & Preterm & Term & Preterm & Term & Preterm & Term \\
\hline Colostrum & 49 & 54 & 2.7 & 2.0 & 2.2 & 1.8 & 5.1 & 5.6 \\
\hline Mature milk & 73 & 63 & 1.1 & 1.0 & 3.3 & 3.4 & 6.2 & 6.5 \\
\hline Difference & $49 \%$ & $16 \%$ & $-61 \%$ & $-52 \%$ & $50 \%$ & $93 \%$ & $21 \%$ & $16 \%$ \\
\hline \multirow[t]{3}{*}{$p$-value } & $<0.00001^{*}$ & $<0.00001^{*}$ & $<0.00001^{*}$ & $<0.00001^{*}$ & $<0.00001^{*}$ & $<0.00001^{*}$ & $<0.00001^{*}$ & $<0.00001^{*}$ \\
\hline & \multicolumn{2}{|c|}{ Calcium } & \multicolumn{2}{|c|}{ Phosphate } & & & & \\
\hline & Preterm & Term & Preterm & Term & & & & \\
\hline Colostrum & 25 & 26 & 9.5 & 11 & & & & \\
\hline Mature milk & 29 & 26 & 12.8 & 16 & & & & \\
\hline Difference & $13 \%$ & $-2 \%$ & $35 \%$ & $41 \%$ & & & & \\
\hline$p$-value & 0.003 & 0.62 & 0.002 & 0.001 & & & & \\
\hline
\end{tabular}

*met our approximate Bonferroni adjusted p-value criteria for statistical significance was $<0.001$.

Colostrum was milk collected in the first 3 days, mature milk was collected between 5 to 12 weeks. The difference values less than $100 \%$ reflect lower values for mature milk, differences greater than $100 \%$ reflect higher values for colostrum compared to mature milk. 


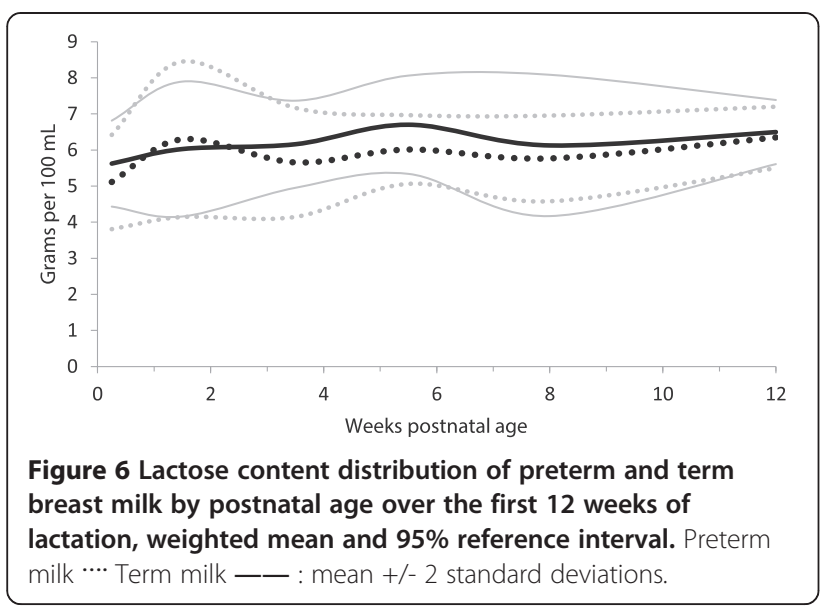

factors used to calculate the energy contributions of the macronutrients and also from assuming that all of the nitrogen was protein $[6,19,22]$ and that the only carbohydrate was lactose $[6,19,121]$, which would contribute to an over- and an under-estimation, respectively, of the energy content of the milk [6].

The mean protein in early preterm milk was higher than in term milk at some time points during the first weeks, but also of importance, the variability of the protein content in preterm milk was twice that of term milk at most time points. The decrease in protein content and variance with postnatal age for preterm and term milk were similar over time. Although the differences in protein content between preterm and term milk were statistically significant for several time points, the differences may be only likely of clinical importance in the first few postnatal days. The meta-analysis revealed that protein content of preterm early milk may be very low in some mothers, based on the calculated reference intervals (mean +/- two (1.96) standard deviations, assuming that the milk composition was not skewed) of 0 to $5.6 \mathrm{~g} / \mathrm{dl}$.

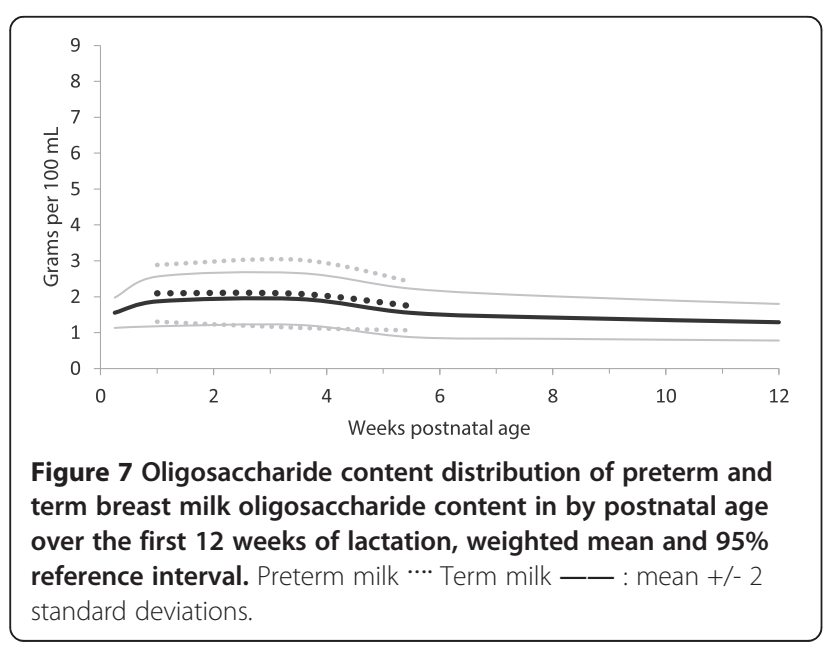

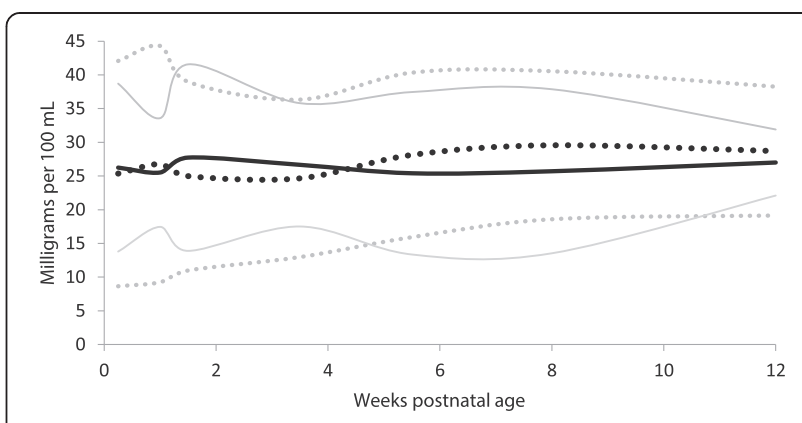

Figure 8 Calcium content distribution of preterm and term breast milk calcium content in by postnatal age over the first 12 weeks of lactation, weighted mean and $95 \%$ reference interval. Preterm milk $\cdots$... Term milk - - : mean +/- 2 standard deviations.

However biological parameters often are skewed. Further research is needed to describe the preterm milk protein distribution, range, and distribution symmetry.

The most dramatic changes from colostrum to mature milk was the decrease in protein and increase in fat, in both preterm and term milk, as well as the increase in energy in preterm milk (Table 7). There is evidence that the protein content of breast milk continues to decrease over time after birth, as revealed by analyses of donor breast milk reports that donated breast milk contains on average 0.9 grams of protein per $100 \mathrm{~mL}[110,113,148]$. One of these studies of donated milk assessed the milk protein content at 8 months of postnatal age, and found the protein was $0.7 \mathrm{~g} / \mathrm{dL}$ [110]. These studies did not meet our inclusion criteria since the milk from both preterm and term delivering mothers were combined $[110,113,148]$.

Some researchers presented their estimates of breast milk protein content based on the total nitrogen, assuming that all of the nitrogen represented protein $[6,11-14$, $18-23,120,122,123,125,128-135]$, some presented both protein estimates [11-14,18,128,129], while other researchers reported only true protein estimates [11-14,18,19,121-123,

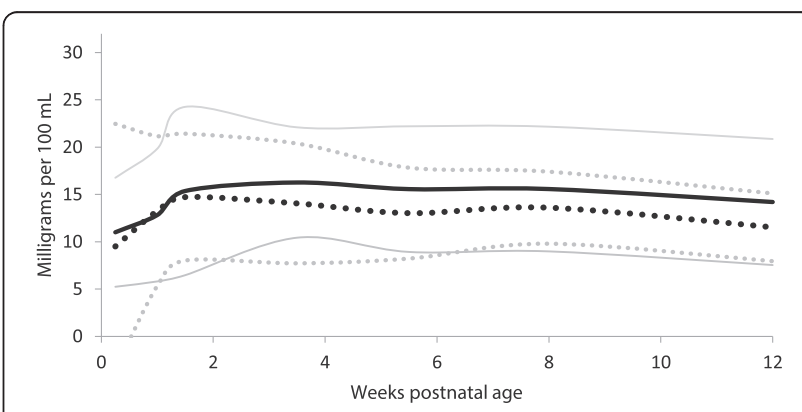

Figure 9 Phosphate content distribution of preterm and term breast milk by postnatal age over the first 12 weeks of lactation, weighted mean and $95 \%$ reference interval. Preterm milk $\cdots \cdot$ Term milk - - : mean $+/-2$ standard deviations. 
127-129,136-139]. The protein meta-analysis estimates based on total protein were almost uniformly higher than the true protein estimates, which suggest that these two approaches should not be averaged together. It has been suggested that the higher protein content of colostrum and early milk compared with later postnatal ages may not be digestible since much of this early non-protein nitrogen is non-digestible lactoferrin and IgA $[128,149]$. If some of this "protein" is not digestible, then it would not be available to meet nutritional protein needs.

This study was limited by the availability of results from the individual studies, and the various milk collection and analysis methods used. The minor undulations in the graphs may not represent real changes in breast milk nutrient content, but be due to differences between the studies and their methods. Another limitation was the limited sample sizes for some of the analyses.

\section{Conclusion}

The protein content of breast milk decreases after birth to be less than half of the colostrum content by 6 weeks. Most of the differences in true protein between preterm and term milk were within $0.2 \mathrm{~g} / \mathrm{dL}$, and by 3 months of age, term milk may have the same protein content as preterm milk. The four parameters assessed in this study (postnatal age, gestational stage (preterm versus term), protein estimated from nitrogen versus measured protein content, and energy calculated from macronutrients versus measured using bomb calorimetry) were all found to be important predictors of breast milk content.

This meta-analysis evidence revealed that breast milk is highly variable between individuals. If breast milk energy macronutrient and mineral content cannot be directly analyzed for the individual mother and infant, the average values from these meta-analyses may provide useful estimates of the milk content.

For future research, our meta-analyses suggest that breast milk energy content calculated from the macronutrients provide poor estimates of measured energy and that protein estimated from the nitrogen overestimates the true protein milk content.

\section{Competing interests}

The authors declare that they have no competing interests.

\section{Authors' contributions}

DG and TRF independently searched the literature, DG attempted to contact authors when the data was not included in a form that could be extracted from the papers, DG extracted the data; TRF checked the data for accuracy and performed the meta-analyses. DG wrote the first draft of the paper and both authors contributed to the analysis and writing of the manuscript. Neither author has any conflicts of interest. All authors read and approved the final manuscript.

\section{Author details}

${ }^{1}$ Department of Pediatrics, University of Calgary, 2888 Shaganappi Trail NW, Calgary, AB T3B 6A8, Canada. ${ }^{2}$ Nutrition Services, Alberta Health Services,
Department of Community Health Sciences, Alberta Children's Hospital Research Institute, Faculty of Medicine, University of Calgary, 3rd Floor, 3280 Hospital Drive NW, Calgary, AB T2N 4Z6, Canada.

Received: 1 May 2014 Accepted: 22 August 2014

Published: 30 August 2014

\section{References}

1. American Academy of Pediatrics Section on Breastfeeding: Breastfeeding and the use of human milk. Pediatrics 2012, 129(3):e827-e841.

2. The Canadian Paediatric Society Nutrition Committee: Exclusive breastfeeding should continue to six months. Paediatrics Child Health 2005, 10(3):148.

3. Kramer MS, Kakuma R: Optimal duration of exclusive breastfeeding. Cochrane Database Syst Rev 2002, 1:003517.

4. Agostoni C, Buonocore G, Carnielli VP, De Curtis M, Darmaun D, Decsi T, Domellof M, Embleton ND, Fusch C, Genzel-Boroviczeny O, Goulet O, Kalhan SC, Kolacek S, Koletzko B, Lapillonne A, Mihatsch W, Moreno L, Neu J, Poindexter B, Puntis J, Putet G, Rigo J, Riskin A, Salle B, Sauer P, Shamir R, Szajewska H, Thureen P, Turck D, van Goudoever JB, Ziegler EE, ESPGHAN Committee on N: Enteral nutrient supply for preterm infants: commentary from the European Society of Paediatric Gastroenterology, Hepatology and Nutrition Committee on Nutrition. J Pediatric Gastroenterol Nutr 2010, 50(1):85-91.

5. Committee N, Canadian Paediatric Society: Nutrient needs and feeding of premature infants. Can Med Assoc J 1995, 152(11):1765-1785.

6. Saarela T, Kokkonen J, Koivisto M: Macronutrient and energy contents of human milk fractions during the first six months of lactation. Acta Paediatr 2005, 94(9):1176-1181.

7. Khan S, Hepworth AR, Prime DK, Lai CT, Trengove NJ, Hartmann PE: Variation in fat, lactose, and protein composition in breast milk over 24 hours: associations with infant feeding patterns. J Hum Lact 2013, 29(1):81-89.

8. Kociszewska-Najman B, Borek-Dzieciol B, Szpotanska-Sikorska M, Wilkos E, Pietrzak B, Wielgos M: The creamatocrit, fat and energy concentration in human milk produced by mothers of preterm and term infants. $J$ Matern Fetal Neonatal Med 2012, 25(9):1599-1602.

9. Lubetzky R, Littner Y, Mimouni FB, Dollberg S, Mandel D: Circadian variations in fat content of expressed breast milk from mothers of preterm infants. J Am Coll Nutr 2006, 25(2):151-154.

10. Nichols BL: Atwater and USDA nutrition research and service: a prologue of the past century. J Nutr 1994, 124(9 Suppl):1718S-1727S.

11. Hibberd CM, Brooke OG, Carter ND, Haug M, Harzer G: Variation in the composition of breast milk during the first 5 weeks of lactation: implications for the feeding of preterm infants. Arch Dis Child 1982, 57(9):658-662

12. Lemons JA, Moye $L$, Hall D, Simmons M: Differences in the composition of preterm and term human milk during early lactation. Pediatr Res 1982, 16(2):113-117

13. Butte NF, Garza C, Johnson CA, Smith EO, Nichols BL: Longitudinal changes in milk composition of mothers delivering preterm and term infants. Early Hum Dev 1984, 9(2):153-162.

14. Schanler RJ, Oh W: Composition of breast milk obtained from mothers of premature infants as compared to breast milk obtained from donors. J Pediatr 1980, 96(4):679-681.

15. Atkinson SA, Radde IC, Chance GW, Bryan MH, Anderson GH: Macromineral content of milk obtained during early lactation from mothers of premature infants. Early Hum Dev 1980, 4(1):5-14.

16. United Nations: Composition of macro geographical (continental) regions, geographical sub-regions, and selected economic and other groupings. http://unstats.un.org/unsd/methods/m49/m49regin.htm\#developed.

17. Stroup DF, Berlin JA, Morton SC, Olkin I, Williamson GD, Rennie D, Moher D, Becker BJ, Sipe TA, Thacker SB SB: Meta-analysis of observational studies in epidemiology: a proposal for reporting. Meta-analysis Of Observational Studies in Epidemiology (MOOSE) group. JAMA 2000, 283(15):2008-2012.

18. Anderson DM, Williams FH, Merkatz RB, Schulman PK, Kerr DS, Pittard WB: 3rd, Length of gestation and nutritional composition of human milk. Am J Clin Nutr 1983, 37(5):810-814.

19. Atkinson SA, Bryan MH, Anderson GH: Human milk feeding in premature infants: protein, fat, and carbohydrate balances in the first two weeks of life. J Pediatr 1981, 99(4):617-624. 
20. Corvaglia L, Battistini B, Paoletti V, Aceti A, Capretti MG, Faldella G: Near-infrared reflectance analysis to evaluate the nitrogen and fat content of human milk in neonatal intensive care units. Arch Dis Child Fetal Neonatal 2008, 93(5):F372-F375.

21. Ferris AM, Dotts MA, Clark RM, Ezrin M, Jensen RG: Macronutrients in human milk at 2, 12, and 16 weeks postpartum. J Am Diet Assoc 1988, 88(6):694-697.

22. Maas YG, Gerritsen J, Hart AA, Hadders-Algra M, Ruijter JM, Tamminga P, Mirmiran M, Spekreijse H: Development of macronutrient composition of very preterm human milk. Br J Nutr 1998, 80(1):35-40.

23. Yamawaki N, Yamada M, Kan-no T, Kojima T, Kaneko T, Yonekubo A: Macronutrient, mineral and trace element composition of breast milk from Japanese women. J Trace Elem Med Biol 2005, 19(2-3):171-181.

24. Neville MC, Keller R, Seacat J, Lutes V, Neifert M, Casey C, Allen J, Archer P. Studies in human lactation: milk volumes in lactating women during the onset of lactation and full lactation. Am J Clin Nutr 1988, 48(6):1375-1386.

25. Ballard O, Morrow AL: Human milk composition: nutrients and bioactive factors. Pediatr Clin North Am 2013, 60(1):49-74.

26. Baumgartner G: The composition of breast milk. Kinderkrankenschwester 2004, 23(6):232-234

27. Bode L: Human milk oligosaccharides: every baby needs a sugar mama. Glycobiology 2012, 22(9):1147-1162.

28. Bokor S, Koletzko B, Decsi T: Systematic review of fatty acid composition of human milk from mothers of preterm compared to full-term infants. Ann Nutr Metab 2007, 51(6):550-556.

29. Cockburn F: Milk composition-the infant human diet. Proc Nutr Soc 1983 42(3):361-373

30. Donovan SM: Human milk: Nutritional properties. In Nutrition in Pediatrics: Basic Science and Clinical Applications. 4th edition. Edited by Duggan C Watkins JB, Walker WA. Hamilton, Ontario, Canada: BC Decker, Inc; 341-353. Chapter 30.

31. Fomon SJ, Ziegler EE: Milk of the premature infant's mother: interpretation of data. J Pediatr 1978, 93(1):164.

32. Picciano MF: Nutrient composition of human milk. Pediatr Clin North Am 2001, 48(1):53-67.

33. Raiha NC: Milk protein quantity and quality and protein requirements during development. Adv Pediatr 1989, 36:347-368.

34. Reali A, Greco F, Fanaro S, Atzei A, Puddu M, Moi M, Fanos V: Fortification of maternal milk for very low birth weight (VLBW) pre-term neonates. Early Hum Dev 2010, 86(Suppl 1):33-36.

35. Schanler RJ: Suitability of human milk for the low-birthweight infant. Clin Perinatol 1995, 22(1):207-222

36. Tudehope DI, Mitchell F, Cowley DM: A comparative study of a premature infant formula and preterm breast milk for low birthweight infants. Aust Paediatr J 1986, 22(3):199-205.

37. Davies DP: How suitable is human milk for pre-term babies? Acta Paediatr Jpn 1989, 31(4):439-454.

38. Tudehope D, Vento M, Bhutta Z, Pachi P: Nutritional requirements and feeding recommendations for small for gestational age infants. J Pediat 2013, 162(3 Suppl):S81-S89.

39. Butte NF, Wong WW, Garza C, Stuff JE, Smith EO, Klein PD, Nichols BL: Energy requirements of breast-fed infants. J Am Coll Nutr 1991, 10(3):190-195.

40. Aprile Mda M, Feferbaum R, Andreassa N, Leone C: Growth of very low birth weight infants fed with milk from a human milk bank selected according to the caloric and protein value. Clinics (Sao Paulo) 2010, 65(8):751-756

41. Atinmo T, Omololu A: Trace element content of breastmilk from mothers of preterm infants in Nigeria. Early Hum Dev 1982, 6(3):309-313.

42. Braga LP, Palhares DB: Effect of evaporation and pasteurization in the biochemical and immunological composition of human milk. J Pediat (Rio J) 2007, 83(1):59-63.

43. Charpak N, Ruiz JG, KMC T: Breast milk composition in a cohort of pre-term infants' mothers followed in an ambulatory programme in Colombia. Acta Paediatr 2007, 96(12):1755-1759.

44. Grumach AS, Jeronimo SE, Hage M, Carneiro-Sampaio MM: Nutritional factors in milk from Brazilian mothers delivering small for gestational age neonates. Rev Saude Publica 1993, 27(6):455-462.

45. Gupta AP, Bhandari B, Gupta A, Goyal S: Mineral content of breast milk from north Indian mothers giving birth preterm and at term-implication for mineral nutrition of preterm infants. J Trop Pediatr 1984, 30(5):286-288.
46. Jitta JN, Musoke RN, Bwibo NO, Kioni J: Composition of early human milk of Kenyan mothers of preterm and term infants. East Afr Med J 1986, 63(11):693-698.

47. Narang AP, Bains HS, Kansal S, Singh D: Serial composition of human milk in preterm and term mothers. Indian J Clin Biochem 2006, 21(1):89-94.

48. Trugo NM, Donangelo CM, Koury JC, Silva MI, Freitas LA: Concentration and distribution pattern of selected micronutrients in preterm and term milk from urban Brazilian mothers during early lactation. Eur J Clin Nutr 1988, 42(6):497-507

49. Anderson GH, Atkinson SA, Bryan MH: Energy and macronutrient content of human milk during early lactation from mothers giving birth prematurely and at term. Am J Clin Nutr 1981, 34(2):258-265.

50. Bauer J, Gerss J: Longitudinal analysis of macronutrients and minerals in human milk produced by mothers of preterm infants. Clin Nutr 2011, 30(2):215-220.

51. Bertino E, Coppa GV, Giuliani F, Coscia A, Gabrielli O, Sabatino G, Sgarrella M, Testa T, Zampini L, Fabris C: Effects of Holder pasteurization on human milk oligosaccharides. Int J Immunopathol Pharmacol 2008, 21(2):381-385.

52. Boehm G, Springer S, Kirchner B: Consequences of the composition of breast milk for the nutrition of underweight newborn infants. I. Calcium and phosphorus. Kinderarztl Prax 1988, 56(9):429-435.

53. Boehm G, Springer S, Lorenz I, Muller DM, Beyreiss K: Consequences of various protein contents in breast milk for the nutrition of the underweight newborn infant. Kinderarztl Prax 1986, 54(1):25-30.

54. Boehm G, Springer S, Muller DM, Senger H: Consequences of the composition of breast milk for the nutrition of underweight newborn infants. II. Lipids and lactose. Kinderarzt/ Prax 1989, 57(9):443-450.

55. Davis TA, Nguyen HV, Garcia-Bravo R, Fiorotto ML, Jackson EM, Lewis DS, Lee DR, Reeds PJ: Amino acid composition of human milk is not unique. J Nutr 1994, 124(7):1126-1132.

56. Friel JK, Andrews WL, Jackson SE, Longerich HP, Mercer C, McDonald A, Dawson B, Sutradhar B: Elemental composition of human milk from mothers of premature and full-term infants during the first 3 months of lactation. Biol Trace Elem Res 1999, 67(3):225-247.

57. Galeotti F, Coppa GV, Zampini L, Maccari F, Galeazzi T, Padella L, Santoro L, Gabrielli O, Volpi N: On-line high-performance liquid chromatographyfluorescence detection-electrospray ionization-mass spectrometry profiling of human milk oligosaccharides derivatized with 2-aminoacridone. Anal Biochem 2012, 430(1):97-104

58. Gross SJ, Geller J, Tomarelli RM: Composition of breast milk from mothers of preterm infants. Pediatrics 1981, 68(4):490-493.

59. Simonin C, Ruegg M, Sidiropoulos D: Comparison of the fat content and fat globule size distribution of breast milk from mothers delivering term and preterm. Am J Clin Nutr 1984, 40(4):820-826.

60. Bishara R, Dunn MS, Merko SE, Darling P: Nutrient composition of hindmilk produced by mothers of very low birth weight infants born at less than 28 weeks' gestation. J Hum Lact 2008, 24(2):159-167.

61. Bortolozo EA, Tiboni EB, Candido LM: Milk from human milk banks for low birthweight newborns: nutritional contents and supplementation. Rev Panam Salud Publica 2004, 16(3):199-205.

62. de Halleux $V$, Rigo J: Variability in human milk composition: benefit of individualized fortification in very-low-birth-weight infants. Am J Clin Nutr 2013, 98(2):529S-535S.

63. Genzel-Boroviczeny O, Wahle J, Koletzko B: Fatty acid composition of human milk during the 1st month after term and preterm delivery. Eur J Pediatr 1997, 156(2):142-147.

64. Harzer G, Haug M, Dieterich I, Gentner PR: Changing patterns of human milk lipids in the course of the lactation and during the day. Am J Clin Nutr 1983, 37(4):612-621.

65. Lonnerdal B, Woodhouse LR, Glazier C: Compartmentalization and quantitation of protein in human milk. J Nutr 1987, 117(8):1385-1395.

66. Lucas A, Ewing G, Roberts SB, Coward WA: How much energy does the breast fed infant consume and expend? Br Med J (Clin Res Ed) 1987, 295(6590):75-77.

67. Mitoulas LR, Kent JC, Cox DB, Owens RA, Sherriff JL, Hartmann PE: Variation in fat, lactose and protein in human milk over $24 \mathrm{~h}$ and throughout the first year of lactation. Br J Nutr 2002, 88(1):29-37.

68. Molto-Puigmarti C, Castellote Al, Carbonell-Estrany X, Lopez-Sabater MC: Differences in fat content and fatty acid proportions among colostrum, transitional, and mature milk from women delivering very preterm, preterm, and term infants. Clin Nutr 2011, 30(1):116-123. 
69. Velona T, Abbiati L, Beretta B, Gaiaschi A, Flauto U, Tagliabue P, Galli CL, Restani P: Protein profiles in breast milk from mothers delivering term and preterm babies. Pediatr Res 1999, 45(5 Pt 1):658-663.

70. Bitman J, Wood L, Hamosh M, Hamosh P, Mehta NR: Comparison of the lipid composition of breast milk from mothers of term and preterm infants. Am J Clin Nutr 1983, 38(2):300-312.

71. de Figueiredo CS, Palhares DB, Melnikov P, Moura AJ, dos Santos SC: Zinc and copper concentrations in human preterm milk. Biol Trace Elem Res 2010, 136(1):1-7.

72. Aquilio E, Spagnoli R, Seri S, Bottone G, Spennati G: Trace element content in human milk during lactation of preterm newborns. Biol Trace Elem Res 1996, 51(1):63-70.

73. Arslanoglu S, Moro GE, Ziegler EE: The Wapm Working Group On, Nutrition: Optimization of human milk fortification for preterm infants: new concepts and recommendations. J Perinat Med 2010, 38(3):233-238.

74. Bao Y, Chen C, Newburg DS: Quantification of neutral human milk oligosaccharides by graphitic carbon high-performance liquid chromatography with tandem mass spectrometry. Anal Biochem 2013, 433(1):28-35.

75. Barros MD, Carneiro-Sompaio MM: Milk composition of low birth weight infants' mothers. Acta Paediatr Scand 1984, 73(5):693-694.

76. Bishara R, Dunn MS, Merko SE, Darling P: Volume of foremilk, hindmilk, and total milk produced by mothers of very preterm infants born at less than 28 weeks of gestation. J Hum Lact 2009, 25(3):272-279.

77. Boehm G, Senger H, Friedrich M, Muller DM, Beyreiss K: Protein supplementation of human milk for the nutrition of VLBW-infants: human milk protein vs. meat protein hydrolysate. Klin Padiatr 1990, 202(5):316-320.

78. Chan GM: Human milk calcium and phosphate levels of mothers delivering term and preterm infants. J Pediatric Gastroenterol Nutr 1982, 1(2):201-205.

79. Charlwood J, Tolson D, Dwek M, Camilleri P: A detailed analysis of neutral and acidic carbohydrates in human milk. Anal Biochem 1999, 273(2):261-277.

80. De Curtis M, Brooke OG: Energy and nitrogen balances in very low birthweight infants. Arch Dis Child 1987, 62(8):830-832.

81. Funkquist EL, Tuvemo T, Jonsson B, Serenius F, Hedberg-Nyqvist K: Growth and breastfeeding among low birth weight infants fed with or without protein enrichment of human milk. Ups J Med Sci 2006, 111(1):97-108.

82. Fusch G, Choi A, Rochow N, Fusch C: Quantification of lactose content in human and cow's milk using UPLC-tandem mass spectrometry. J Chromatogr B Analyt Technol Biomed Life Sci 2011, 879(31):3759-3762.

83. Hill PD, Aldag JC, Chatterton RT, Zinaman M: Comparison of milk output between mothers of preterm and term infants: the first 6 weeks after birth. J Hum Lact 2005, 21(1):22-30.

84. Lonnerdal B: Effects of milk and milk components on calcium, magnesium, and trace element absorption during infancy. Physiol Rev 1997, 77(3):643-669.

85. Lucas A, Hudson GJ: Preterm milk as a source of protein for low birthweight infants. Arch Dis Child 1984, 59(9):831-836.

86. Lyon AJ, McIntosh N: Calcium and phosphorus balance in extremely low birthweight infants in the first six weeks of life. Arch Dis Child 1984, 59(12):1145-1150.

87. Manz F: Protein quantity and quality in term and preterm infants: effects on urine creatinine and expression of amino acid excretion data. J Pediatr Gastroenterol Nutr 1986, 5(5):830-831.

88. Mataloun MM, Leone CR: Human milk mineral intake and serum concentrations of calcium and phosphorus in newborn term infants: influence of intrauterine growth restriction. Acta Paediatr 2000, 89(9):1093-1097.

89. Meier PP, Engstrom UL, Murtaugh MA, Vasan U, Meier WA, Schanler RJ: Mothers' milk feedings in the neonatal intensive care unit: accuracy of the creamatocrit technique. J Perinatol 2002, 22(8):646-649.

90. Meier PP, Engstrom JL, Zuleger JL, Motykowski JE, Vasan U, Meier WA, Hartmann PE, Williams TM: Accuracy of a user-friendly centrifuge for measuring creamatocrits on mothers' milk in the clinical setting. Breastfeed Med 2006, 1(2):79-87.

91. Moran JR, Vaughan R, Stroop S, Coy S, Johnston H, Greene HL: Concentrations and total daily output of micronutrients in breast milk of mothers delivering preterm: a longitudinal study. J Pediatric Gastroenterol Nutr 1983, 2(4):629-634.
92. Ogechi AA, William O, Fidelia BT: Hindmilk and weight gain in preterm very low-birthweight infants. Pediatr Int 2007, 49(2):156-160.

93. O'Neill EF, Radmacher PG, Sparks B, Adamkin DH: Creamatocrit analysis of human milk overestimates fat and energy content when compared to a human milk analyzer using mid-infrared spectroscopy. J Pediatr Gastroenterol Nutr 2013, 56(5):569-572.

94. Pamblanco $M$, Ten $A$, Comin J: Proteins in preterm and term milk from mothers delivering appropriate or small-for-gestational age infants. Early Hum Dev 1986, 14(3-4):267-272.

95. Polberger S, Lonnerdal B: Simple and rapid macronutrient analysis of human milk for individualized fortification: basis for improved nutritional management of very-low-birth-weight infants? J Pediatr Gastroenterol Nutr 1993, 17(3):283-290.

96. Svenningsen NW, Lindroth M, Lindquist B: A comparative study of varying protein intake in low birthweight infant feeding. Acta Paediatr Scand Supp/ 1982, 296:28-31.

97. Unanian GS: Level of the trace elements copper, manganese, silicon, aluminum and magnesium in the colostrum, intermediate and mature milk of mothers of full-term and premature newborn infants. Zhurnal Eksper i Klinicheskoi Med 1967, 7(6):96-99.

98. Wang CD, Chu PS, Mellen BG, Shenai JP: Creamatocrit and the nutrient composition of human milk. J Perinatol 1999, 19(5):343-346.

99. Zofkova I, Taborsky P, Bednar J, Nedvidkova J: Lack of stimulating effect on thyrotropic and lactotropic secretion during prolonged calcitriol administration. Exp Clin Endocrinol 1992, 99(1):54-56.

100. Dai D, Tang Z: Copper, iron and zinc content of preterm and term human milk and cow's milk. Hua Xi Yi Ke Da Xue Xue Bao 1991, 22(4):428-431. Hua-Hsi i Ko Ta Hsueh Hsueh Pao.

101. Kalhoff H, Manz F, Kiwull P, Kiwull-Schone H: Food mineral composition and acid-base balance in preterm infants. Eur J Nutr 2007, 46(4):188-195

102. Kovacs A, Funke S, Marosvolgyi T, Burus I, Decsi T: Fatty acids in early human milk after preterm and full-term delivery. J Pediatric Gastroenterol Nutr 2005, 41(4):454-459.

103. Raiha N: Quantity and quality of milk protein intake: metabolic responses in the neonate. J Pediatr Gastroenterol Nutr 1983, 2(Suppl 1):S260-S265.

104. Reichman B, Chessex P, Verellen G, Putet G, Smith JM, Heim T, Swyer PR: Dietary composition and macronutrient storage in preterm infants. Pediatrics 1983, 72(3):322-328.

105. Sanchez-Hidalgo VM, Flores-Huerta S, Matute G, Serrano C, Urquieta B, Espinosa $\mathrm{R}$ : Whey protein/casein ratio and nonprotein nitrogen in preterm human milk during the first 10 days postpartum. J Pediatric Gastroenterol Nutr 1998, 26(1):64-69.

106. Schanler RJ, Abrams SA: Postnatal attainment of intrauterine macromineral accretion rates in low birth weight infants fed fortified human milk. J Pediatr 1995, 126(3):441-447.

107. Wharton BA, Scott PH, Berger HM: Dietary protein for low birthweight babies. Sources and assessment of requirements. Acta Paediatr Scand Suppl 1982, 296:32-37.

108. Butte NF, Wong WW, Hopkinson JM, Heinz CJ, Mehta NR, Smith EO: Energy requirements derived from total energy expenditure and energy deposition during the first 2 y of life. Am J Clin Nutr 2000, 72(6):1558-1569.

109. de Bruin NC, Degenhart HJ, Gal S, Westerterp KR, Stijnen T, Visser HK: Energy utilization and growth in breast-fed and formula-fed infants measured prospectively during the first year of life. Am J Clin Nutr 1998, 67(5):885-896.

110. Michaelsen KF, Skafte L, Badsberg JH, Jorgensen M: Variation in macronutrients in human bank milk: influencing factors and implications for human milk banking. J Pediatric Gastroenterol Nutr 1990, 11(2):229-239

111. Stein H, Cohen D, Herman AA, Rissik J, Ellis U, Bolton K, Pettifor J, MacDougall L: Pooled pasteurized breast milk and untreated own mother's milk in the feeding of very low birth weight babies: a randomized controlled trial. J Pediatr Gastroenterol Nutr 1986, 5(2):242-247.

112. Stellwagen LM, Vaucher YE, Chan CS, Montminy TD, Kim JH: Pooling expressed breastmilk to provide a consistent feeding composition for premature infants. Breastfeed Med 2013, 8:205-209.

113. Wojcik KY, Rechtman DJ, Lee ML, Montoya A, Medo ET: Macronutrient analysis of a nationwide sample of donor breast milk. J Am Diet Assoc 2009, 109(1):137-140. 
114. Butte NF, Wong WW, Hopkinson JM: Energy requirements of lactating women derived from doubly labeled water and milk energy output. J Nutr 2001, 131(1):53-58.

115. Heinig MJ, Nommsen LA, Peerson JM, Lonnerdal B, Dewey KG: Energy and protein intakes of breast-fed and formula-fed infants during the first year of life and their association with growth velocity: the DARLING Study. Am J Clin Nutr 1993, 58(2):152-161.

116. Stuff JE, Nichols BL: Nutrient intake and growth performance of older infants fed human milk. J Pediatr 1989, 115(6):959-968.

117. Brooke O, Carter N, Hibberd C, Wood C, Brown I: Protein concentrations in milk from mothers of preterm and term infants. Biochem Soc Trans 1981, 9(1):69-70.

118. Leveque B: Composition of maternal milk in the first month of lactation and milk formulas for infants. Ann Pediatr (Paris) 1986, 33(4):355-358.

119. Sadurskis A, Kabir N, Wager J, Forsum E: Energy metabolism, body composition, and milk production in healthy Swedish women during lactation. Am J Clin Nutr 1988, 48(1):44-49.

120. Lepage G, Collet S, Bougle D, Kien LC, Lepage D, Dallaire L, Darling P, Roy CC: The composition of preterm milk in relation to the degree of prematurity. Am J Clin Nutr 1984, 40(5):1042-1049.

121. Thomas MR, Chan GM, Book LS: Comparison of macronutrient concentration of preterm human milk between two milk expression techniques and two techniques for quantitation of energy. J Pediatric Gastroenterol Nutr 1986, 5(4):597-601.

122. Butte NF, Garza C, Stuff JE, Smith EO, Nichols BL: Effect of maternal diet and body composition on lactational performance. Am J Clin Nutr 1984, 39(2):296-306.

123. Butte NF, Wong WW, Ferlic L, Smith EO, Klein PD, Garza C: Energy expenditure and deposition of breast-fed and formula-fed infants during early infancy. Pediatr Res 1990, 28(6):631-640.

124. Garza C, Butte NF: Energy concentration of human milk estimated from 24-h pools and various abbreviated sampling schemes. J Pediatr Gastroenterol Nutr 1986, 5(6):943-948.

125. Motil KJ, Sheng HP, Montandon CM, Wong WW: Human milk protein does not limit growth of breast-fed infants. J Pediatr Gastroenterol Nutr 1997, 24(1):10-17.

126. Wood CS, Isaacs PC, Jensen M, Hilton HG: Exclusively breast-fed infants: growth and caloric intake. Pediatr Nurs 1988, 14(2):117-124.

127. Nommsen LA, Lovelady CA, Heinig MJ, Lonnerdal B, Dewey KG: Determinants of energy, protein, lipid, and lactose concentrations in human milk during the first 12 mo of lactation: the DARLING Study. Am J Clin Nutr 1991, 53(2):457-465.

128. Beijers RJ, Graaf FV, Schaafsma A, Siemensma AD: Composition of premature breast-milk during lactation: constant digestible protein content (as in full term milk). Early Hum Dev 1992, 29(1-3):351-356.

129. Itabashi K, Miura A, Okuyama K, Takeuchi T, Kitazawa S: Estimated nutritional intake based on the reference growth curves for extremely low birthweight infants. Pediatr Int 1999, 41(1):70-77.

130. Arnold J, Leslie G, Chen S: Protein, lactose and fat concentration of breast milk of mothers of term and premature neonates. Aust Paediatr J 1987, 23(5):299-300

131. Gross SJ, David RJ, Bauman L, Tomarelli RM: Nutritional composition of milk produced by mothers delivering preterm. J Pediatr 1980, 96(4):641-644.

132. Reinken L, Dockx F: Vitamin B6- and protein concentrations in breast milk from mothers of preterm and term infants. Klin Padiatr 1985 197(1):40-43.

133. Faerk J, Skafte L, Petersen S, Peitersen B, Michaelsen KF: Macronutrients in milk from mothers delivering preterm. Adv Exp Med Biol 2001, 501:409-413.

134. Hosoi S, Honma K, Daimatsu T, Kiyokawa M, Aikawa T, Watanabe S: Lower energy content of human milk than calculated using conversion factors. Pediatr Int 2005, 47(1):7-9.

135. Cregan MD, De Mello TR, Kershaw D, McDougall K, Hartmann PE: Initiation of lactation in women after preterm delivery. Acta Obstet Gynecol Scand 2002, 81(9):870-877.

136. Montagne P, Cuilliere ML, Mole C, Bene MC, Faure G: Immunological and nutritional composition of human milk in relation to prematurity and mother's parity during the first 2 weeks of lactation. J Pediatric Gastroenterol Nutr 1999, 29(1):75-80.

137. Britton JR: Milk protein quality in mothers delivering prematurely: implications for infants in the intensive care unit nursery setting. J Pediatric Gastroenterol Nutr 1986, 5(1):116-121.
138. Sanchez-Pozo A, Lopez J, Pita ML, Izquierdo A, Guerrero E, Sanchez-Medina F, Martinez Valverde A, Gil A: Changes in the protein fractions of human milk during lactation. Ann Nutr Metab 1986, 30(1):15-20.

139. Michaelsen KF, Larsen PS, Thomsen BL, Samuelson G: The Copenhagen cohort study on infant nutrition and growth: duration of breast feeding and influencing factors. Acta Paediatr 1994, 83(6):565-571.

140. Coppa GV, Gabrielli O, Pierani P, Catassi C, Carlucci A, Giorgi PL: Changes in carbohydrate composition in human milk over 4 months of lactation. Pediatrics 1993, 91(3):637-641

141. Coppa GV, Pierani P, Zampini L, Gabrielli O, Carlucci A, Catassi C, Giorgi PL: Lactose, oligosaccharide and monosaccharide content of milk from mothers delivering preterm newborns over the first month of lactation. Minerva Pediatr 1997, 49(10):471-475.

142. Ehrenkranz RA, Ackerman BA, Nelli CM: Total lipid content and fatty acid composition of preterm human milk. J Pediatric Gastroenterol Nutr 1984, 3(5):755-758.

143. Gabrielli O, Zampini L, Galeazzi T, Padella L, Santoro L, Peila C, Giuliani F, Bertino E, Fabris C, Coppa GV: Preterm milk oligosaccharides during the first month of lactation. Pediatrics 2011, 128(6):e1520-e1531.

144. Guerrini P, Bosi G, Chierici R, Fabbri A: Human milk: relationship of fat content with gestational age. Early Hum Dev 1981, 5(2):187-194.

145. Hurgoiu V, Caseanu E: Mineral composition of the milk of mothers of premature infants during early lactation. Pediatrie 1986, 41(6):469-473.

146. Sann L, Bienvenu F, Lahet C, Bienvenu J, Bethenod M: Comparison of the composition of breast milk from mothers of term and preterm infants. Acta Paediatr Scand 1981, 70(1):115-116.

147. Viverge D, Grimmonprez L, Cassanas G, Bardet L, Solere M: Variations in oligosaccharides and lactose in human milk during the first week of lactation. J Pediatr Gastroenterol Nutr 1990, 11(3):361-364.

148. Valentine CJ, Fernandez S, Rogers LK, Gulati P, Hayes J, Lore P, Puthoff T, Dumm M, Jones A, Collins K, Curtiss J, Hutson K, Clark K, Welty SE: Early amino-acid administration improves preterm infant weight. $J$ Perinatol 2009, 29(6):428-432.

149. Donovan SM, Atkinson SA, Whyte RK, Lonnerdal B: Partition of nitrogen intake and excretion in low-birth-weight infants. Am J Dis Child 1989, 143(12):1485-1491.

\section{doi:10.1186/1471-2431-14-216}

Cite this article as: Gidrewicz and Fenton: A systematic review and meta-analysis of the nutrient content of preterm and term breast milk. BMC Pediatrics 2014 14:216.

\section{Submit your next manuscript to BioMed Central and take full advantage of:}

- Convenient online submission

- Thorough peer review

- No space constraints or color figure charges

- Immediate publication on acceptance

- Inclusion in PubMed, CAS, Scopus and Google Scholar

- Research which is freely available for redistribution 